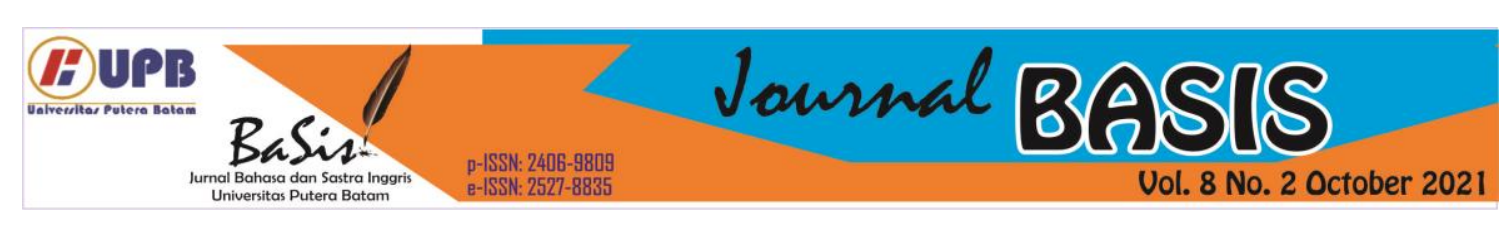

\title{
THE EFFECTIVENESS OF THIEVES STRATEGY TOWARDS STUDENTS' READING COMPREHENSION AT THE ELEVENTH GRADE OF SMAN 19 TEBO
}

\author{
Rauldatul Husni ${ }^{1}$ \\ Universitas Dharmas Indonesia (UNDHARI), Dharmasraya, Indonesia \\ usnii91@gmail.com ${ }^{1}$ \\ Lina Candra Wati ${ }^{2}$ \\ Universitas Dharmas Indonesia (UNDHARI), Dharmasraya, Indonesia \\ lcandrawati@yahoo.com ${ }^{2}$
}

\begin{abstract}
This research explore the Effectiveness of "thieves" Strategy Towards Students' Reading Comprehension at the Eleventh Grade of SMAN 19 Tebo. The problems of this research are students lack of vocabulary, students did not have good motivation in reading text and the students have difficulty in comprehending texts. The purpose of the research is to know the effectiveness of THIEVES strategy towards students' reading comprehension at the eleventh grade of SMAN 19 Tebo. This research focus on the quantitative research. The population in this study all 11 grades at SMAN 19 Tebo. In this study, the total population is 29, consist of class 11 IPS and 11 MIPA. Then, the sample in this study 11 IPS and II MIPA. Based on practical teaching English at SMAN 19 Tebo, the researcher find some problems in the class. Therefore the researcher applies strategy in reading, with this strategy students learn the THIEVES strategy before students read the text. The research findings indicate that the use of THIEVES strategy was able to improve the students' reading comprehension. The conclusions ofthis research is supported by the post-test results of students' reading comprehension at the eleventh grade students of SMAN 19 Tebo. The mean post-test experimental class is 78.75 and in the control class is 71.69. The differerence score between experimental class and control class was 7.06. The researcher find a positive impact on the experimental class. It means that students' reading comprehension in experimental class was significantly improve and there is significantly different effect between experimental class and control class which teach by using THIEVES and without THIEVES. It indicates that the null hypothesis (H0) is rejected and the alternative hypothesis (Ha) is accepted. It presents that the THIEVES strategy give a significant effect on students' reading comprehension of report text.
\end{abstract}

Keywords: THIEVES Strategy, Reading Comprehension, Report text.

\section{INTRODUCTION}

English is an International language used for communication, because English is the most used language by countries in communication between other countries. According to Afriana (2015), English is one of the international languages that is used by

the people worldwide to communication. In education, English is one lesson that students must learn. English is a foreign language learned by students from Junior high school to university. In terms of reading skill, the curriculum 2013, concerning standard 
competence requires students to understand the meaning of short functional text and essays in the form of a report, narrative, analytical exposition, spoof, and hortatory exposition. According to Riadil and Romadhon (2020), the 2013 curriculum is a new curriculum in Indonesia that low interest in writing and reading. It makes the goverment through the Ministry of Education and Culture launched a literacy program in schools. Curriculum 2013 is a design of learning to develop the potential of learners and to realize a noble, healthy, knowledgeable, capable, creative, independent, democratic, and responsible Indonesian generation with dignity, high civilization, culture, character, faith, and piety to God Almighty (Kemendikbud, 2013). But in reality, students still have poor reading comprehension.

Reading comprehension is a students process texts, understand the meaning of the texts, and know the content of the text. Comprehension is a process in which readers make meaning with the aid interact with the text through the combination of prior knowledge and experience, the information in the text and the readers views relating to the text (Duke 2008, as cited in Udin, 2018). In reading, students interact with a text through a combination of knowledge and previous experience with the textand students are able to find information inside the text. Reading comprehension is indispensable for students. Based on practical teaching English at SMA Negeri 19 Tebo, students still poor in reading comprehension. So the students score in reading comprehension is less than the maximum. Such as the score of reading comprehension in analytical exposition text in table 1.1.

Table 1.1 Analytical exsposition text score at SMAN 19 Tebo

\begin{tabular}{|c|c|c|c|c|c|c|c|}
\hline \multirow{2}{*}{ No } & \multirow{2}{*}{ Class name } & \multirow{2}{*}{ KKM } & \multirow{2}{*}{$\begin{array}{l}\text { Students } \\
\text { number }\end{array}$} & \multicolumn{4}{|c|}{ Score } \\
\hline & & & & Complete & $\%$ & Incomplete & $\%$ \\
\hline 1 & Class XI IPA & $\begin{array}{l}6 \\
6 \\
\end{array}$ & 13 & 8 & $62 \%$ & 5 & $\begin{array}{l}38 \\
\% \\
\end{array}$ \\
\hline 2 & Class XI IPS & $\begin{array}{l}6 \\
6\end{array}$ & 16 & 9 & $\begin{array}{l}56 \\
\%\end{array}$ & 7 & $\begin{array}{l}44 \\
\%\end{array}$ \\
\hline
\end{tabular}

There are three problems for reading comprehension. First, students lack of vocabulary. The lack of vocabulary in the English language is influenced by several factors, such as lack of knowledge or vocabulary meaning. The use of learning strategies that can attract students to reading learning. According to Intrasombat (2002, as cited in Khataee, 2019), the influence of vocabulary development on reading comprehension showed that many students had limited vocabulary skills and that this area caused problems with English reading comprehension. Based on explanation above, there are still many students who have lack of vocabulary in reading, whereas vocabulary in reading comprehension is very important for students to know the meaning of the text.

Second, students did not have good motivation in reading text. There are still many students who do not have motivation in learning to read. Usually, teachers do not make students a center 
in the learning process activities. According to Sari (2019), the teacher did not make the students a center in class. The teacher just tells the student for reading the text and translating the text, so that the student has no activity other than listening to the teacher. The impact on reading is that students more difficult in having a good motivation to read a text, because students are tired of learning.

Third, the students have difficulty in comprehending texts. Students feel confused because they do not understand the content of the text. According to Shofia (2001, as cited in Soemantri, 2011), in the research it is found that the weak points of the students in terms of reading speed and reading comprehension have two elements or factors. Students do not fully comprehend how to read the text and how to comprehend it well. This factor makes students unhappy in class because in learning students only monotone in the text. The effect on students is that students are difficult to understand the text well. Then students also find it difficult to get the meaning of some unknown words in the text.

Therefore, based on the problems stated above, the researcher applies THIEVES as the strategy in teaching reading. THIEVES strategy make students thinking. Students have to do read the big picture view of the chapter, search for information and summarize. In the classroom, before reading the whole text, students can look for the main idea of text, with THIEVES strategy students are able to analyze the main ideas and supporting details of the text (Benedict 2012, as cited in Novia, 2013). So, in this strategy the students easier to find out information from the text. According to Zwiers (2018:87), THIEVES is an acronym that helps students go through all the necessary pre reading steps before diving into a textbook chapter and get students to build extensive knowledge of the text even before they read the first normal words of a chapter.

The THIEVES strategy is a strategy that can be used by teachers in teaching reading. According to Sidiq (2018), THIEVES strategy will give contribution for students in the learning process. As a result THIEVES strategy will contribute to students in learning English, especially reading. Students learn how to search information from title, heading, introduction, each first sentence, visual and vocabulary, end of chapter questions and summary. In this strategy, it students is easier to know information from the text. THIEVES strategy is a strategy that helps students through all the necessary pre-read steps before reading the totality text. Finally, based on the background above the researcher use strategy "The Effectiveness of THIEVES Strategy Towards Students' Reading Comprehension at the Eleventh Grades of SMAN 19 Tebo".

\section{LITERATURE REVIEW}

\subsection{Reading Comprehension}

Reading comprehension is an understanding of a text read by students. In reading comprehension students are expected to get the information contained in text, books, short story and other. Reading comprehension need good concentration, so that the information we read can be delivered. According to Grabe and Stoller (2002, as cited in Pamuji, 2015), states that reading comprehension is the main purpose of reading, which underlies most other reading purposes, supports them, and is more complex than commonly thought. If the reader assumes the purpose, he gets the meaning of the text and can understand 
the text.

On the other hand, Collingwood (2015:1), states that reading comprehension is important, not only for understanding the text, but for broader learning, success in education, and employment. Reading comprehension is a complex task, that requires the orchestration of many different cognitive abilities and skills.

Furthermore, Koonce (2018), states that reading comprehension is the construction of the meaning of a written text through a reciprocal exchange of ideas between the reader and the particular message of the text, it involves intentional thinking, activation of various cognitive capacities (attention, inference, memory) and construction of interaction of specific knowledge of the interaction between the text and the reader.

In conclusion, reading comprehension is an understanding of the text read by students. Reading comprehension is the development of the meaning of written text through the exchange of reciprocal ideas between readers, not only to understand the text but for broader learning and to be able to understand the meaning of the text that has been read. The difference between reading and reading comprehension, reading is process that students in reading text and reading comprehension is process of understanding the content of the text to get information.

\subsection{THIEVES Strategy}

Strategy in learning is very important, learning strategies are used by teachers in learning activities. Starategy in reading very much, such as THIEVES strategy. Strategies help teachers to explain the general components of materials and procedures for obtaining goals prepared by teachers before teaching. THIEVES strategy is a pre- reading strategy that defines the purpose of reading using an easily remembered acronym. Students learn information from the title, headings, introduction, every first sentence, visuals and vocabulary, end of chapter questions, and summary, before reading the entire text selection. Using THIEVES helps readers can identify key concepts, establish a context for reading, and predict what ideas might be contained in a text passage.

According to Benedict (2012, as cited in Sari, 2013), THIEVES (title, heading, introduction, every first sentence, visual and vocabulary, end of chapter questions, summary) is a reading strategy to build extensive knowledge of the students when reading a text. This strategy is to analyze the main idea and supporting detail from the text. According to Zwiers (2018:87), THIEVES is an acronym that helps students go through all the necessary prereading steps before diving into a textbook chapter and get students to build extensive knowledge of the text even before they read the first normal words of a chapter.

According to Manz (2002, as cited in Khataee, 2019), this strategy is described to previewing texts and use the acronym THIEVES: Title, Headings, Introduction, Every first sentence in a paragraph, Visuals and vocabulary, end of chapter questions, and summary. Instructions for how to introduce and apply the strategy in elementary schools and colleges were explained.

Based on the statement above, the THIEVES strategy is a strategy used in reading. This strategy is described for previewing text and using acronyms: title, heading, introduction, each first sentence in a paragraph, visual and vocabulary, end of chapter questions, 
and summary. The THIEVES strategies to build students' extensive knowledge while reading the text before they read the content of a chapter. THIEVES strategy is able to apply by teachers in reading learning activities before the student reads all the text.

\subsection{The Element of THIEVES Strategy}

THIEVES strategy has seven elements namely, title, heading, introduction, every first sentence in a paragraph, visuals and vocabulary, end of chapter questions, and summary.

According to Manz (2002), there is an element of the THIEVES strategy for reading. First, title: the title is the entrance into a chapter, most often it states the topic. Second, headings: headings are the gateway to the important general subject area within the chapter. Third, introduction: the introduction typically provides a framework into which the chapter content may be placed. Chapter goals and setting for the text. four, every first sentence in a paragraph: for a very through preview, students are asked to read the first sentence of the paragraph. Five, visual and vocabulary: for visual learners, it is an opportunity to integrate an important processing sense. Vocabulary terms help unlock the meaning of the chapter. Six, end of chapter questions: culminating study questions often flag important points and concepts. Knowledge of the end chapter questions helps direct and establish a purpose for reading. Last, summary: typically at the conclusion of the chapter, students are encouraged to read the entire summary part of their preview.

According to Gear (2008), there are seven element of THIEVES such as: T (title), $\mathrm{H}$ (heading), I (introduction), $\mathrm{E}$ (every first sentence), V (visual and vocabulary), E (ending), S (summary). Learning using THIEVES strategy helps students to identify important concept in texts.

According to Al-Faki \& Siddiek (2013), there is an element of THIEVES strategy. First, title: students sometimes skip the title, but it provides valuable information by establishing the topic and the context of the chapter. Second, headings: headings indicate the important sections of the chapter. Heading, help students identify the specific topics covered. Third, introduction: the introduction provides an overview of the chapter. Introduction exists after the title and before the first heading. Four, every first sentence in a paragraph: first sentences are often the topic sentences of the paragraph, and by reading these a student can get an idea of the information that will be contained in the chapter. Five, visuals and vocabulary: students should look at all pictures, charts, tables, maps, and graphs contained in the chapter. They need to read the captions and labels on each text. This allows students to learn a little about the topic before they begin to read. Six, end of chapter questions:many texts contain a summary at the end of the chapter. Students read the summary to activate prior knowledge and give them an idea of the important concepts contained in the chapter. Last, summary: enhances comprehension and retention of the information and ideas encountered during reading.

Based on the explanation above, the element of THIEVES strategy consists of the title, heading, introduction, every first sentence in paragraph, visual and vocabulary, end of chapter questions, and summary, with the element of THIEVES strategy students are able to see acronym in THIEVES. 


\section{RESEARCH METHOD}

The type of research is experimental research. According to Creswell (2012, as cited in Shahzad, 2019), experimental is test an idea practice or precedure to determine whether in influences an outcome or dependent variable. The design in this study is true experimental design. According to Sugiyono (2017:75), true experimental design is a sample used first condition of the difference between the experimental group and the control group.

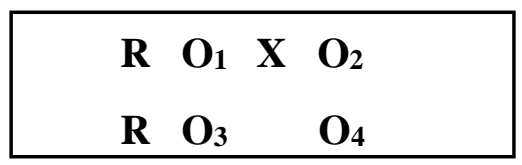

Picture 3.1 Design research pretest-posttest control group design

Source: Sugiyono (2017: 76)

Explanation :

$\mathrm{R}=$ Random Sampling

$\mathrm{X}=$ Treatment (Application of THIEVES strategy)

$\mathrm{O} 1=$ Pretest experimental class

$\mathrm{O}_{2}=$ Posttest experimental class

$\mathrm{O}_{3}=$ Pretest control class

$\mathrm{O}_{4}=$ Posttest control class for the experiment as well as a control group taken random from a specific population, with the control group and samples selected random. The form of design used in this study pretestposttest control group design. According to Sugiyono (2017:76), pretest-posttest control group design is two groups random selected, and then given a pretest.

\subsection{Result}

This study was conducted at the eleventh grade students of SMAN 19 Tebo from May to July 2021. The research took XI IPA as the control class and XI IPS as the experimental class. The experimental class and control class were taught in different strategy in teaching reading. The experimental class was taught report text using THIEVES strategy, whereas control class was taught report text by using conventional strategy.

The data of students reading comprehension was taken from the results of students' scores in their final test. The reading test was conducted in the experimental class and control class. The test that were given to students were the same characteristic and same question. The result of two class was compared by using SPSS 20.

\section{RESULT AND DISCUSSION}

Table 4.1 Post-Test Result of Students Reading Comprehension Score

\begin{tabular}{lccccccc}
\hline \multicolumn{1}{c}{ Class } & $\mathbf{N}$ & Mean & Max & Min & Std & Variance & Sum \\
\hline $\begin{array}{l}\text { Experime } \\
\text { ntal class }\end{array}$ & 1 & 78,75 & 88 & 72 & 4,31 & 18,600 & $\mathbf{1 2 6 0}$ \\
\hline $\begin{array}{l}\text { Control } \\
\text { class }\end{array}$ & $\mathbf{1}$ & $\mathbf{7 1 , 6 9}$ & $\mathbf{8 0}$ & $\mathbf{6 0}$ & $\mathbf{4 , 7 5}$ & $\mathbf{2 2 , 5 6 4}$ & $\mathbf{9 3 2}$ \\
\hline
\end{tabular}

The table above shows that the calculate of post-test scores of students reading comprehension after treatment were given by the researcher. It presents that the mean of experimental class after giving treatment was 78.75 while control class was 71.69. Moreover, the maximum score of experimental class 
was 88 , while control class 80 . The minimum score of experimental class was 72 and the control class was 60 . The standard deviation of experimental class was 4.312 and 4.750 in control class. The variance of experimental class was 18.600 and 22.564 in control class. The sum of experimental class was 1260 and 932 in control class.

\subsection{Discussion}

The main purpose of this research is to know the effectiveness of THIEVES strategy towards students' reading comprehension at the eleventh grade of SMAN 19 Tebo. Based on the research, this research was divided into some phases. There are the preparation phase, application phase, and final phase. In the preparation phase, the lesson plan was designed by the researcher. In the application phase, the researcher implemented THIEVES as the treatment. In the final phase, the posttest for experimental class and control class. This study proved that there was significance difference in scores between the students' reading comprehension with THIEVES and without THIEVES.

Based on the result of analysis data, it can be explained that after the researcher teaching reading by using the THIEVES strategy, the researcher found that the students who were taught by using the THIEVES strategy gave positive effect on their reading comprehension. It is because this strategy helps students in comprehending the text. The strategy is very effective in improving students' comprehension of what their read because the students know the main idea and information of text before they read whole text. According to Manz (2002, as cited in Khatee, 2019), THIEVES is a pre-reading strategy that set the purpose for reading using easily remembered acronym. Students learn how "steal" information from the title, headings, introduction, every first sentence in a paragraph, visual and vocabulary, end of chapter questions, and summary.

In teaching learning, the researcher gives test to the students. The test was multiple choice questions that is consist of 25 items with five options a, b, c, d and e. Then, the researcher gave the pre-test to both class, experimental and control class. In the experimental class, the researcher explained material that would be taught. Then, the researcher gave the students report text and tried to activate their background knowledge related to the topic given. Then the researcher explained about report text and acronym THIEVES. The researcher gave question to the students for guiding them in reading text. After the researcher gave question, the researcher asked to the students to answer with THIEVES based on the topic and to find main idea. Then, the researcher and the students discussed students' answer. The last, the researcher asked to the students to answer the multiple choice question to measure what is student understand or not. The difference in every meeting wasin the topic given. In the control class, the teacher using the conventional strategy, where the teacher explained the report text and gives an example of the report text then the student was asked to do the assignment.

After the treatments were given, the researcher gave post-test for the students to know their reading comprehension ability after they got the treatments. Based on the result of students' posttest, the mean score in the experimental class was 78.75 meanwhile, the control class 71.69. It can see the difference between experimental class and control class score is not far. The differerence score between experimental class and 
control class was 7.06. It can be seen from the maximum score of the experimental class and control class. The maximum score in experimental class was 88 , meanwhile control class 80 . The score given by the THIEVES strategy was higher than the control class, becuase in experimental class the researcher apply the THIEVES strategy to identify important information from reading the text and make the students easy to understand of the text based on the component of the THIEVES.

The THIEVES strategy had significant effect on students' reading comprehension in reading report text. According to Della (2019), teaching reading comprehension by using THIEVES strategy on explanation text was significantly effective and different from teaching without THIEVES strategy. The THIEVES strategy is easy to learn and it can make teaching and learning report text more effective, it is proved the students taught by using THIEVES strategy obtained better score in post-test, than the students taught reading comprehension without THIEVES strategy had low score in post-test.

Based on the syllabus in Senior High School at the second grade, there are four materials, namely: report text, narrative text, analytical exposition text, and explanation text, in this research, the researcher only focused on report text. The researcher applied THIEVES strategy in teaching report text. Based on research, in the control class, one of the students had a medium score in the pre-test and post- test. While the experimental class during pre-test students' score are low and after given treatment the experimental class score becomes high.

The results of the post-test prove that there is an effect using THIEVES in the experimental class. The students' result in experimental class was higher than the students result in control class. The experimental score was higher than the control class because of the treatment of the THIEVES strategy in the experimental class. According to Della (2019), the students treated by using the THIEVES strategy in experimental class achieved better score than control class taught reading without THIEVES strategy. The result of the hypothesis found t-test $=4.189$ and t-table $=2.052$ at the level of significance $=0.05$. It shows that t-test $>\mathrm{t}$-table. It means that using THIEVES able increase students' reading comprehension in report text.

\section{CONCLUSION}

Based on the previous chapter that has been discussed about the results of the research, the conclusions of this research is supported by the post-test results of students' reading comprehension at the eleventh grade students of SMAN 19 Tebo. The mean post-test experimental class is 78.75 and in the control class is 71.69 . It could be concluded that the mean score post-test of experimental class is higher than control class. It means that students' reading comprehension in experimental class was significantly improved and there is significantly different effect between experimental class and control class which taught by using THIEVES and without THIEVES. Based on the analysis it can be concluded that there is significant different in reading comprehension between the eleventh grade students of SMAN 19 Tebo.

\section{REFERENCES}

Afriana, afriana. Analysis of Students' Reading Strategies At Riau Kepulauan University. Jurnal Basis, [s.1.], v. 2, n. 1, p. 9-24, apr. 2015. issn 2527-8835. 
http://ejournal.upbatam.ac.id/index. php/basis/article/view/2756

Al-Faki, \& Siddiek, (2013). The Role of Background Knowledge in Teahcing Reading Comprehension. World Journal of English Language, $3(4)$. https://doi.org/10.5430/wjel.v3n4p4 $\underline{2}$

Collingwood, (2015). Understanding and teaching reading comprehension. A handbook.

In Educational Psychology in Practice (Vol. 31, Issue 3). https://doi.org/10.1080/02667363.2 $\underline{015.1052233}$

Della, (2019). Let: Linguistics , Literature And English Teaching Journal The Effectiveness Of “ Thieves " Teaching Strategy In Teaching Reading Comprehension At The Second Grade Of Ma Nipi Rakha In The Academic Year Of 2018/2019. 9(2), 265-275.

Khataee, (2019). The Effect of THIEVES Strategy on EFL Learners' Reading Comprehension. International Journal of Instruction.

Khataee, (2019). The effect of THIEVES strategy on EFL learners' reading comprehension. International Journal of Instruction, 12(2), 667-682. https://doi.org/10.29333/iji.2019.12 $242 \mathrm{a}$

Koonce, (2018). Encyclopedia of Clinical Neuropsychology. Encyclopedia of Clinical Neuropsychology, 2002, 56782. https://doi.org/10.1007/978-3-319$\underline{56782-2}$

Manz, (2002). A strategy for previewing textbooks: Teaching readers to become THIEVES. Reading Teacher, 55(5), 434-435.

Nanda, (2019). Improving Students' Reading Comprehension In
Descriptive Text Through Thieves (Title, Heading, Introduction, Every First Sentence, Visual/Vocabulary, End Of The Text, And Summary) Strategy At Vii Grade Students Mts Negeri 2 Labuhanbatu Utara Skripsi (Vol. 87, Issue 1,2). UIN Sumatera Utara. Novia, (2013). Teaching Reading Narrative Text By Using. 21-29.

Pamuji, (2015). The Correlation Among Attitude, Reading Comprehension, And Writing Achievement Of English Education Study Program Students Of Sriwijaya University. Jurnal Adminika, 1(1), 17-28.

Riadil, I. G., \& Romadhon, F. (2020). The Digital Native Students' Preference In Using Newsela As The Media Of Digital Literacy To Enrich Students Vocabulary. IdeBahasa, 2(1), 39-48.

Shahzad, (2019). The Effectiviness Of Thieves Strategy Towards Students Motivation In Reading Comprehension. E-Jurnal Manajemen Universitas Udayana, 4(3), 1-21.

Sidiq, (2018). The Use of Thieves Strategy to Increase Students Reading Tarbiyah and Teacher Training Faculty English Education Department State Islamic Institute of Metro 1439 H / 2018 An Undergraduate Thesis. State Islamic Institute Of Metro.

Soemantri, (2011). Reading Comprehension Problems Encounted By the Students of Higher Education. Jurnal Computech \& Bisnis, 5(2), 74-80. http://jurnal.stmikmi.ac.id/index.ph $\mathrm{p} /$ jcb/article/view/69.

Sugiyono. (2017). Metode Penelitian Kuantitaif, Kualitatif, dan RND. Alfabeta, cv.

Udin, (2018). Reading Comprehension:

A Study on the Correlation between 
Grammar and Logic. LanguaJournal of Linguistics, Literature, and Language Education, 1(1), 6272.

https://doi.org/https://doi.org/10.52 81/zenodo.1415299

Zwiers, (2018). Building Reading Comprehension Habits In Grades 6-12. In Journal of Materials Processing Technology (Vol. 1, Issue 1). 
